\title{
THE NEW EU WATER FRAMEWORK DIRECTIVE AND PARTICIPATIVE EVALUATION PROCESSES: USE OF MULTICRITERIA TOOLS IN THE EVALUATION OF WATER MANAGEMENT OPTIONS IN THE COSTA DEL SOL (SOUTH SPAIN)
}

P. Paneque, S. Corral, A Pereira, L. del Moral, B. Pedregal: The new EU water framework directive and participative evaluation processes: use of multicriteria tools in the evaluation of water management options in the Costa Del Sol (south Spain). - Geografie - Sborník ČGS, 109, 2, pp. 156-169 (2004). - The European Union Water Framework Directive has become an engine of change in water policy, particularly in so far as it prioritises the rational use of water, restoration of the good ecological status of water ecosystems and public participation - diversity of perspectives and values - in decision-making, as a vital instrument to achieve these aims. This paper presents the results of the implementation of a participatory evaluation process to assess water management alternatives for the water supply in the Costa del Sol Occidental area in the province of Malaga. The techniques used in the process were multi-criteria evaluation and social research, with the involvement of the social actors identified in the analysis as a central tenet. It is maintained that by implementing participatory processes, it is possible to arrive at unconventional diagnoses, which can be developed into innovative water management alternatives, and that by taking into account all the values and interests at stake, it is possible to find solutions that overcome inertia, look beyond shortterm considerations and rationalize social conflicts and resistance.

KEY WORDS: water management - integrated evaluation - participation - stakeholders.

\section{Introduction}

The European Union Water Framework Directive has become an engine of change in water policy, particularly in so far as it prioritises the rational use of water in both economic and social terms, restoration of the good ecological status of water ecosystems and public participation in decisionmaking, as a vital instrument to achieve these aims. Based on this threepronged reference framework, the Directive requires the evaluation of all water resource management projects to ensure that they meet established objectives. The ultimate aim of promoting public participation is to map the diversity of perspectives and values that may be brought to bear on water resource management problems and, in this way, improve the quality of the solutions devised and avert conflict after the final decision has been taken.

With a view to proposing a methodology for water management authorities to implement the participatory evaluation of water plans and projects, a project entitled Integrated Evaluation for Sustainable River Basin 
Governance (ADVISOR) is being carried out over the period 2001-2004, as part of the European Commission Fifth Framework Programme for Research. Project participants include the New University of Lisbon (Portugal), the European Commission Joint Research Centre in Ispra (Italy), the University of the Aegean (Greece), the Free University of Amsterdam (Netherlands), the Macaulay Institute in Aberdeen (United Kingdom) and the University of La Laguna, the University of Seville and the University of Pablo de Olavide in Spain. The National Water Institute of Portugal, the Regional Development Agency for the Cyclades Islands in Greece and the Water Department of the Regional Government of Andalusia (Junta de Andalucía) are also taking part in the project as end users ${ }^{2}$.

The ADVISOR project seeks to design such a methodology based on the concept of integrated evaluation, construed as an approach capable of addressing the uncertainty and complexity intrinsic in issues such as the sustainable use of water resources and as a reflective and iterative evaluation process, which takes into account the social environment in which the scientific and political activities are being carried out and which involves laypeople as well as experts and interest groups. In order to accommodate the complexity inherent in social and environmental systems, integrated evaluation seeks to bring together different disciplines and sources and to map the problem under review on an appropriate spatial and political scale, taking into account the numerous connections existing between the two. Another key feature of this approach is that it seeks to ensure that the evaluation activities are not divorced from developments in the political, social and institutional context in which they are carried out. This permits the systematic combination of conventional scientific knowledge and the information generated by other social actors to be used as the basis for environmental action.

On the basis of this theoretical definition, the first ADVISOR work package (2001) focused on the analysis of past evaluations of completed water projects, with a view to drawing conclusions on the methodologies employed and on potential opportunities and obstacles revealed in each case study in order to develop an integrated approach for future evaluation processes. The case studies reviewed included the following: i) construction of a dam on the River Evinos to increase the drinking water supply to the city of Athens (Greece); ii) designation of the River Ythan and estuary as a nitrate vulnerable zone, with a view to reducing high nitrate concentration levels in waters draining off agricultural land, and so improve water quality in areas of great ecological value (Scotland, United Kingdom); iii) project for the extensive rehabilitation of Grensmaas, involving improving flood defence systems, creating natural areas and the extraction of gravel, by restoring the Meuse River flood channel and plain (Netherlands); iv) construction of the Alqueva dam on the River Guadiana to improve irrigation and the overall development of the Alentejo region (Portugal); v) construction of the Ebro transfer to redistribute water resources in Spain by redirecting water from the River Ebro to the Mediterranean coast.

The objective of the project's second work package (2002) was to contribute to the development of an integrated theory for the evaluation of river basin

1 ADVISOR Contract EVK1-CT-2000-00074, EC-Energy, Environment and Sustainable Development RTD Programme. http:/gasa.dcea.fct.unl.pt/ecoman/projects/advisor.

2 A key figure given that it is an applied research project. 


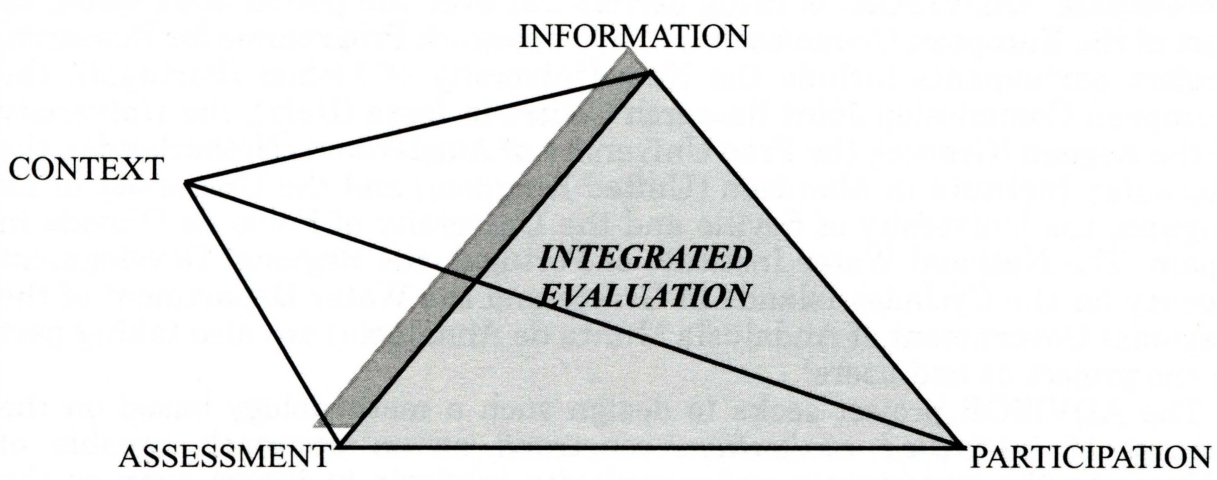

Fig. 1 - Evaluation tetrahedron. Source: Videira et all (2002, p. 163)

projects in the European Union. To this end, the five case studies mentioned above were compared using an approach termed the evaluation tetrahedron (figure 1). This methodological diagram includes the four dimensions of analysis that all evaluation processes should address in order to fulfil the requirements established in the Water Framework Directive: information, assessment, participation and context.

The two work packages carried out to date allow general conclusions to be drawn on current evaluation practice in real-life situations. First, all the projects examined have been approved by the relevant authorities in each case and are currently being implemented, although this does not signify an absence of uncertainty as regards their feasibility or likelihood of completion. Second, assumptions about the unquestionable value of the projects are based on an indisputable diagnosis of the problem and possible solutions, implying that the necessity and technical viability of the projects are self-evident. Furthermore, the projects are clearly formulated on the premise of the indisputable value of the project, based on the assumption that the benefits are always greater than the costs. This should be regarded as a reflection of widely accepted and hegemonic values and long-held traditions in the water policy arena of each country, which are not, however, immune to tensions and conflicts that express the dynamics of change in the social perception of water resources. Lastly, the evaluation processes carried out in the case studies analysed tended to simplify the ecological and social processes at the initial diagnosis stage, failing to examine the causes of the problems identified and the likely consequences of these problems on natural and social systems. Furthermore, uncertainty about how these systems function is not reflected in the situation diagnosis or in the strategic solutions adopted.

These general considerations reveal that the evaluation of the hydrological projects was not regarded as a process required prior to project design and approval, but rather as a matter that could be resolved a posteriori. It is therefore evident that in making a situation diagnosis or considering solutions to the identified problems, the overriding considerations were the values and beliefs that contribute to "myths" about water issues, making difficult, if not impossible, any discussion of solutions other than those established by the "implicit" strategy, that is, those strongly assumed at the start of the process. It can therefore be concluded that the role of evaluation processes to date has been to justify and defend a decision already taken and 


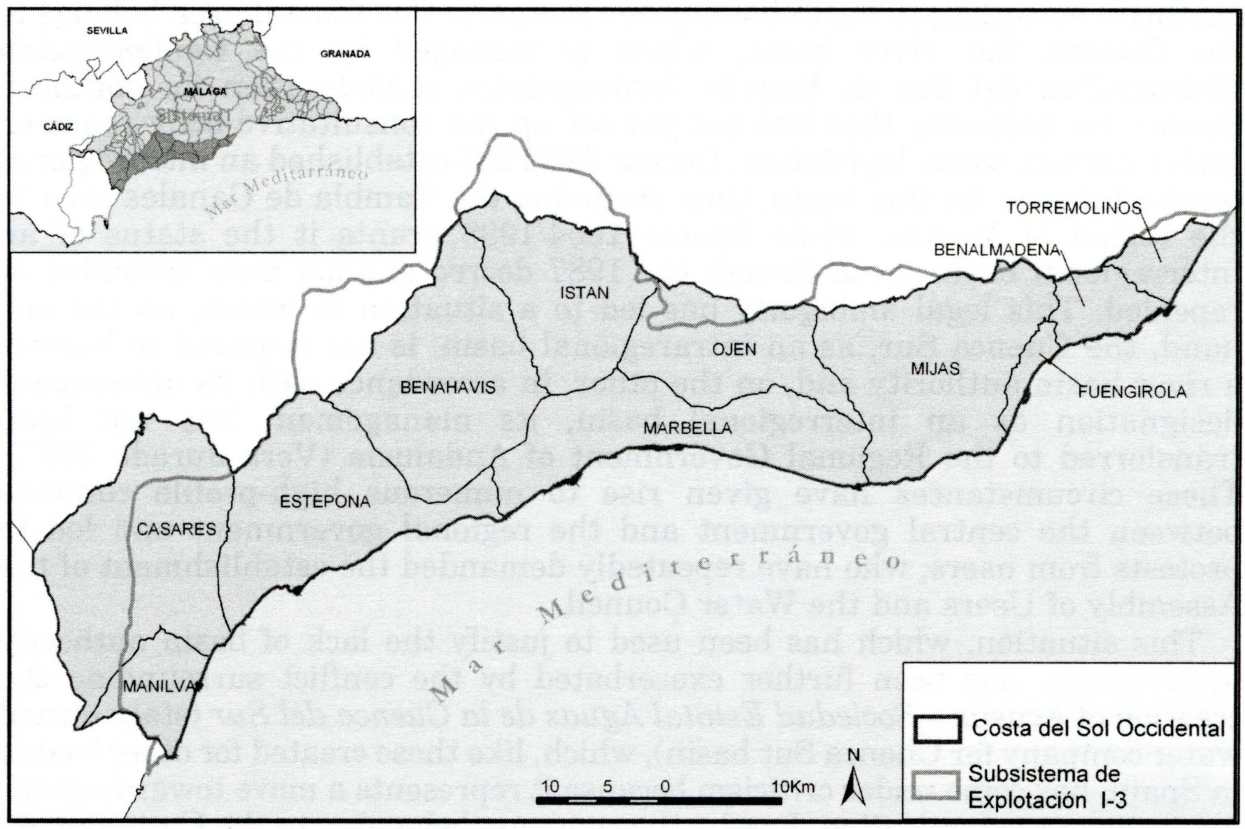

Fig. 2 - Location and boundaries of the area under study. Source: 1:100,000scale digital map of Andalusia. Own elaboration.

not to provide an extensive, integrated evaluation of the issue prior to water policy decisions being taken. This seriously limits the effectiveness and usefulness of information and participation processes, generally leading to more frustration than satisfaction among social stakeholders.

\section{Costa del Sol Occidental (province of Malaga)}

In the third part of the project, methodologies were developed in accordance with the initial concept of integrated water project evaluation, which are useful to the authorities responsible for decision-making in this area. To this end, each participating team proposed a case study to serve as a laboratory to test the proposed methodologies. For this third work package, the Spanish team selected Costa del Sol Occidental in the province of Malaga (figure 2), an area where alternatives for improving the water supply to the coastal strip are currently under debate.

It is an area that has experienced rapid growth in tourism in recent decades, which has led to a transformation of the area's socio-demographic and economic structures, mounting pressure on resources and land use restructuring. This area is particularly relevant as a case study for our purposes because it has suffered bouts of drought, which have highlighted competition and conflict between different water uses, the uncontrolled increase of certain water uses and the lack of forward planning by the competent authorities, whose response has been to instigate reactive emergency measures (Paneque 2003).

Furthermore, the organisational structure of water management in Costa del Sol Occidental is particularly complex, further exacerbating existing 
conflicts. According to basin boundaries in Spain, this coastal area belongs to the Cuenca Sur river basin, which is managed by the Confederación Hidrográfica del Sur de Espana (hydrographic confederation for southern Spain), an authority that has not yet set up the consultative body required under current water legislation. Decree 650/1987 established an intraregional territorial area for this basin, thus excluding the Rambla de Canales area in the region of Murcia, while Decree 1664/1998 grants it the status of an interregional basin, even though the 1987 decree has not been amended or repealed. This legal ambiguity has led to a situation in which, on the one hand, the Cuenca Sur, as an intraregional basin, is not required to become a river basin authority and, on the other, in accordance with its subsequent designation as an interregional basin, its management has not been transferred to the Regional Government of Andalusia (Vera Jurado 2003). These circumstances have given rise to numerous high-profile conflicts between the central government and the regional government and led to protests from users, who have repeatedly demanded the establishment of the Assembly of Users and the Water Council.

This situation, which has been used to justify the lack of basin authority involvement, has been further exacerbated by the conflict surrounding the creation of Acusur - Sociedad Estatal Aguas de la Cuenca del Sur (state-owned water company for Cuenca Sur basin), which, like those created for other basins in Spain, has come under criticism because it represents a move towards water management privatisation. Lastly, the company belonging to the Costa del Sol Occidental Joint Municipal Corporation, Acosol - Aguas y Saneamiento de la Costa del Sol (Costa del Sol water and sewerage), which is responsible for managing water supply and sewerage services in the eleven municipalities that it covers, has also been caught up in controversy. In addition to opposing the attempts of certain town councils to privatise these services - in some cases the matter has been taken to the Andalusian Supreme Court of Justice - it has been involved in a legal battle for the control of the desalination plant in Marbella, the Corporation's main alternative water resource asset.

\section{Proposed methodology}

The methodology proposed to evaluate water management alternatives in such a problematic context is social multi-criteria evaluation, using the NAIADE (Novel Approach to Imprecise Assessment and Decision Environments) model, designed by Munda (1994) and developed by the Joint Research Centre in Ispra (Italy) in 1995. Multi-criteria evaluation can be defined as a set of techniques used to support decision-making processes with the analysis of a number of alternatives, taking into account conflicting interests and multiple criteria, usually including economic, social and environmental factors. By including social considerations, it is ensured that the intervention of scientists in political processes implies a responsibility to society as a whole and not just to decision makers (Munda 2002). As a conflict management tool, multi-criteria evaluation has demonstrated its usefulness in solving many environmental management problems and improves the quality and effectiveness of the decision-making process itself.

The main properties of NAIADE as an evaluation tool are as follows:

It allows the use of information affected by different types and degrees of uncertainty, such as qualitative information (linguistic variables), 
quantitative information, precise information (crisp numbers) and fuzzy information (well defined unlimited numbers), which is of great importance when processing information with a high degree of uncertainty, that is, information that is not wholly accurate, reliable, exhaustive and unequivocal.

NAIADE differs from other multi-criteria methods in that there is no differential weighting of the different criteria used to evaluate the alternatives. All the criteria are given the same weight and are therefore not prioritised according to whether they are economic, environmental or socioinstitutional in nature.

Conflicting values have traditionally been integrated in multi-criteria decision aids either by weighting the criteria used or by taking certain "ethical" evaluation criteria into account. NAIADE proposes a third option based on the application of conflict analysis procedures integrated with multicriteria evaluation to enable decision-makers to take "defensible" or "maintainable" policy decisions that reduce the degree of discrepancy and achieve a compromise solution (Corral 2000).

Therefore, the purpose of the NAIADE model is not to produce an undisputable or "optimum" ranking of alternatives, but to rationalize the problem and provide a horizontal and vertical framework for communication among the social actors involved. This evaluation model is a useful tool in conflict resolution experiences because it implements a participatory and deliberative approach from the moment the problem is defined, identifies the possible alternatives and proposes criteria for pairwise comparison.

NAIADE allows for two types of mutually enriching evaluations. The first is a multi-criteria analysis based on the score values assigned to the criteria of each alternative and performed using a matrix (known as the impact matrix). The second is an equity evaluation, which analyses the value judgements of the stakeholders involved in the evaluation process for each alternative using another matrix (known as the equity matrix) and the possible formation of coalitions (stakeholder groups who defend one of the proposed alternatives). In order to fulfil integrated evaluation objectives, multi-criteria analysis, specifically the NAIADE model, is therefore used in combination with institutional analysis and social research methods. ${ }^{3}$

This methodological framework (figure 3) is used to define the problem to be appraised, determine the scope of study, identify the stakeholders and interests involved and establish the alternatives and criteria proposed by the stakeholders to be discussed in the debate. Once the alternatives have been evaluated, the results of the analysis are presented to all the stakeholders involved in the previous research phases, following the focus group methodology (Dürrenberg et al. 1997, Kasemir et al. 1997, Morgan 1998, McLaughlin 1992) - the analysts facilitate the process and act as observers - with a view to obtaining feedback, sharing and honing the information collected and discussing the results achieved up to that point.

The proposed methodology responds perfectly to the need to open the social debate on water resource allocation to map all the implications, interests and issues surrounding water management and, in this way, find solutions that

3 The combination of participatory and institutional approaches with multi-criteria evaluation was proposed and tested in the VALSE project, specifically in the case study on the evaluation of water management alternatives in the region of Troina in Sicily, which did not seek to provide solutions to existing conflicts, but to progress towards compromise solutions capable of achieving a high degree of consensus among the different stakeholder groups - see De Marchi et al. (2000). 
Stakeholder identification

Definition of problem

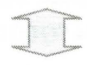

Identification of water management alternatives

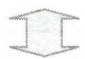

Identification of evaluation criteria for alternatives

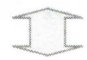

Evaluation of alternatives
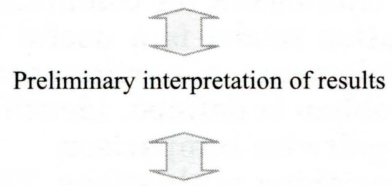

Focus group

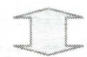

Final interpretation of results

Fig. 3 - Evaluation process methodology diagram contribute to sucesful conflict resolution. It is therefor social actors be identified and selected on the basis of a careful analysis of the social and institutional framework in which they operate.

Guidance on Public Participation in relation to the Water Framework Directive produced by the European Commission, with a view to establishing a common implementation strategy (CIS-WG 2.9, 2002), recommends that the identification and analysis of stakeholders - referred to as "interested parties" - should be carried out by conducting interviews among a selection of all potential stakeholders. In the case under review, the prior selection of stakeholders to be interviewed was made on the basis of an analysis of the context and the legislative framework, supported by an analysis of the national and local press, which helped to identify the individuals and public and private bodies and organizations that play an active part in the water management debate in the area under study. This preliminary list of stakeholders was added to on the basis of suggestions made by those interviewed during the first round of interviews as to who they believed should be included (figure 4). The information provided by the stakeholders in the course of the interviews was then recorded in a written questionnaire completed by the stakeholders after the interviews.

The final selection of stakeholders is not always accepted by all the sectors 


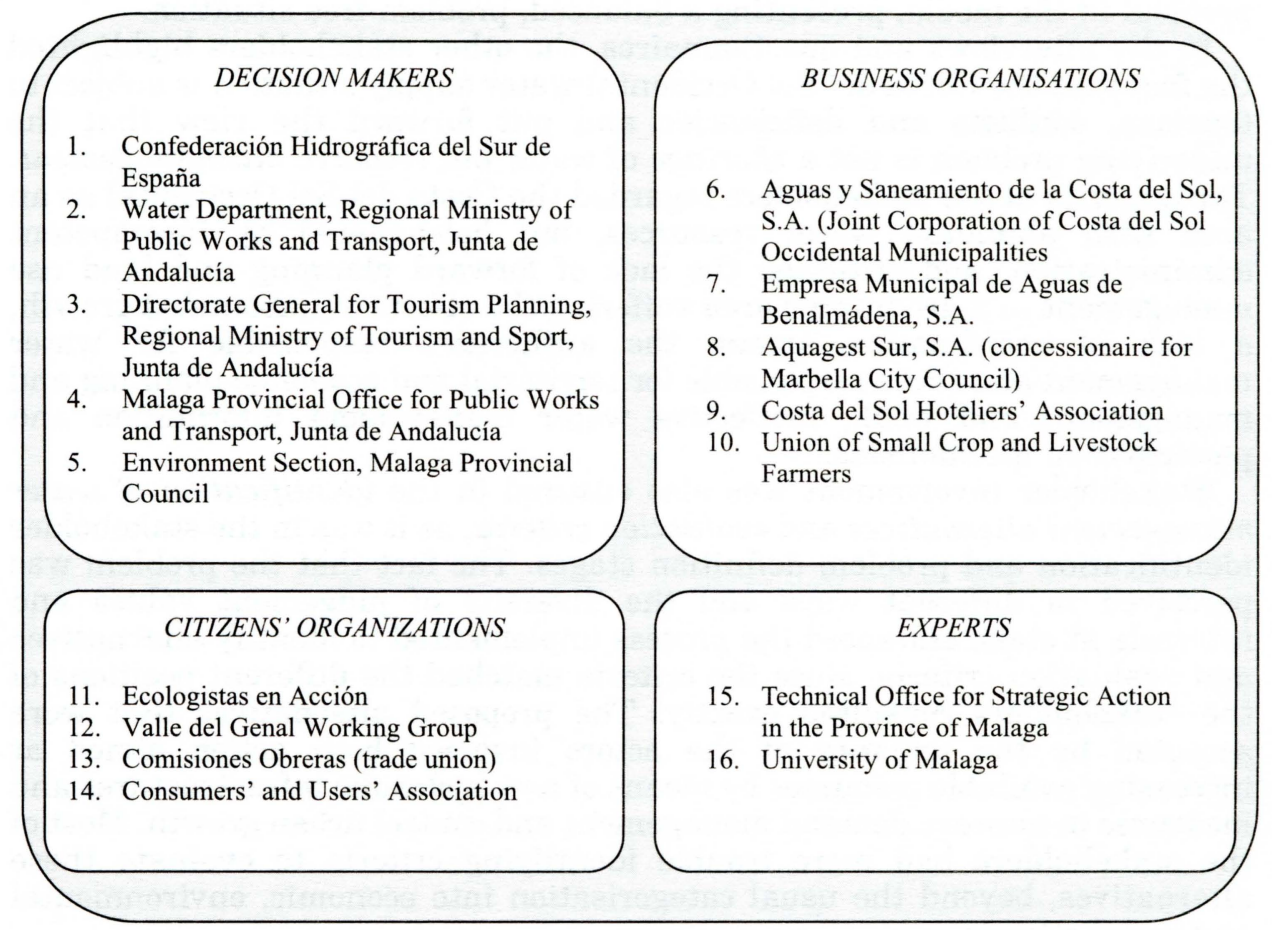

Fig. 4 - Stakeholders identified in the Costa del Sol Occidental area

consulted. In this case, limitations on the number of participants meant leaving out some important players, such as the municipal authorities - a total of 11 in the area under study - which were only indirectly involved in the evaluation exercise through two municipal water companies. Some very influential stakeholders in this coastal area, such as the association of urban developers and construction companies, were not included because they were not willing to participate.

The purpose of the problem definition stage is not simply to describe the situation, but to map the perceptions of the population regarding the issue under review. Therefore, the viewpoints and judgement values expressed by the actors, mainly in the social media and in interviews, are of utmost interest. It is the job of the analysts to consider the different problem definitions put forward by the stakeholders and draw on their own experience to determine what, in their opinion, the core issue is, as public participation does not in any way exempt experts from responsibility.

In the various contacts with the identified stakeholders, two different perceptions of the water problem in the Costa del Sol Occidental area came to light. One was the definition of the problem from the viewpoint of the authority responsible for water resource management in the area, Confederación Hidrográfica del Sur, as reflected in the Cuenca Sur River Basin Hydrological Plan, based on the concept of a structural water deficit, affecting the whole of the river basin and resource use systems located in the area under study. This diagnosis serves as an argument for investment in new hydraulic infrastructures to improve the water supply in the area, in spite of the fact that the authority goes to great lengths to downplay the 
problem in the media, presenting a balanced, problem-free situation.

In the interviews and questionnaires, the other stakeholders highlighted the fact that the Costa del Sol Occidental water supply situation is subject to tensions, conflicts and deficiencies and put forward the view that the underlying problem is not a shortage of water but resource mismanagement. The majority of the stakeholders regarded the Costa del Sol Occidental as an area with abundant water resources, but beleaguered by incompetent administration, and criticised the lack of forward planning and land use management in a geographic area suffering the effects of unbounded growth, a lack of coordination among the authorities responsible for water management and those responsible for territorial and economic planning and management and weak, ineffective water management information and participation mechanisms.

Stakeholder involvement was also ensured in the identification of water management alternatives and evaluation criteria, as it was in the stakeholder identification and problem definition stages. The fact that the problem was perceived in different ways and the diversity of judgement values and interests at stake enhanced the process implemented to identify alternatives and evaluation criteria, since the criteria matched the different positions of the stakeholders consulted exactly. The proposed alternatives that were accepted by the majority of the actors involved both action aimed at increasing available resources by means of new hydraulic infrastructures and measures to improve demand management and control urban growth. Most of the stakeholders had more trouble identifying criteria to evaluate these alternatives, beyond the usual categorisation into economic, environmental and social criteria.

Alternatives: Heightening of the La Concepción dam; Use of desalinated water; Reuse of waste water; Modernisation of irrigation systems; Rationalised use of ground water; Improved efficiency and water savings in the urban water supply; Territorial policies to control urban development; Non-intervention: maintenance of status quo.

Criteria: Implementation costs; Operating costs; Effect on employment; Effect on economic activity; Impact on the ecological status of water systems; Impact on other ecosystems; Visual impact on the landscape; Degree of institutional difficulty; Degree of social acceptance; Equitable distribution of costs and benefits; Time required to fulfil the established objective.

On the basis of the alternatives and criteria identified by the stakeholders, a matrix was constructed with value scores for each of the proposed water management alternatives, according to the eleven evaluation criteria. The matrix was based on data from specialized literature and technical reports, including quantitative, qualitative, crisp and fuzzy values. The results allow a comparison of the alternatives and the generation of a ranking according to the selected criteria. In order to evaluate the proposed alternatives according to the respective positions of the stakeholders, generating a new ranking, the NAIADE model was then used to perform an analysis based on another matrix, reflecting the qualitative assessment of the alternatives made by the participating stakeholders in the written questionnaires (figure 5).

The equity analysis also provides information about the position of the stakeholders on each of the alternatives and the possible formation of coalitions among them to defend or veto a given alternative. This provides an insight into which alternatives are more likely to be accepted, although the highest-ranking alternatives are not necessarily the most feasible. To 


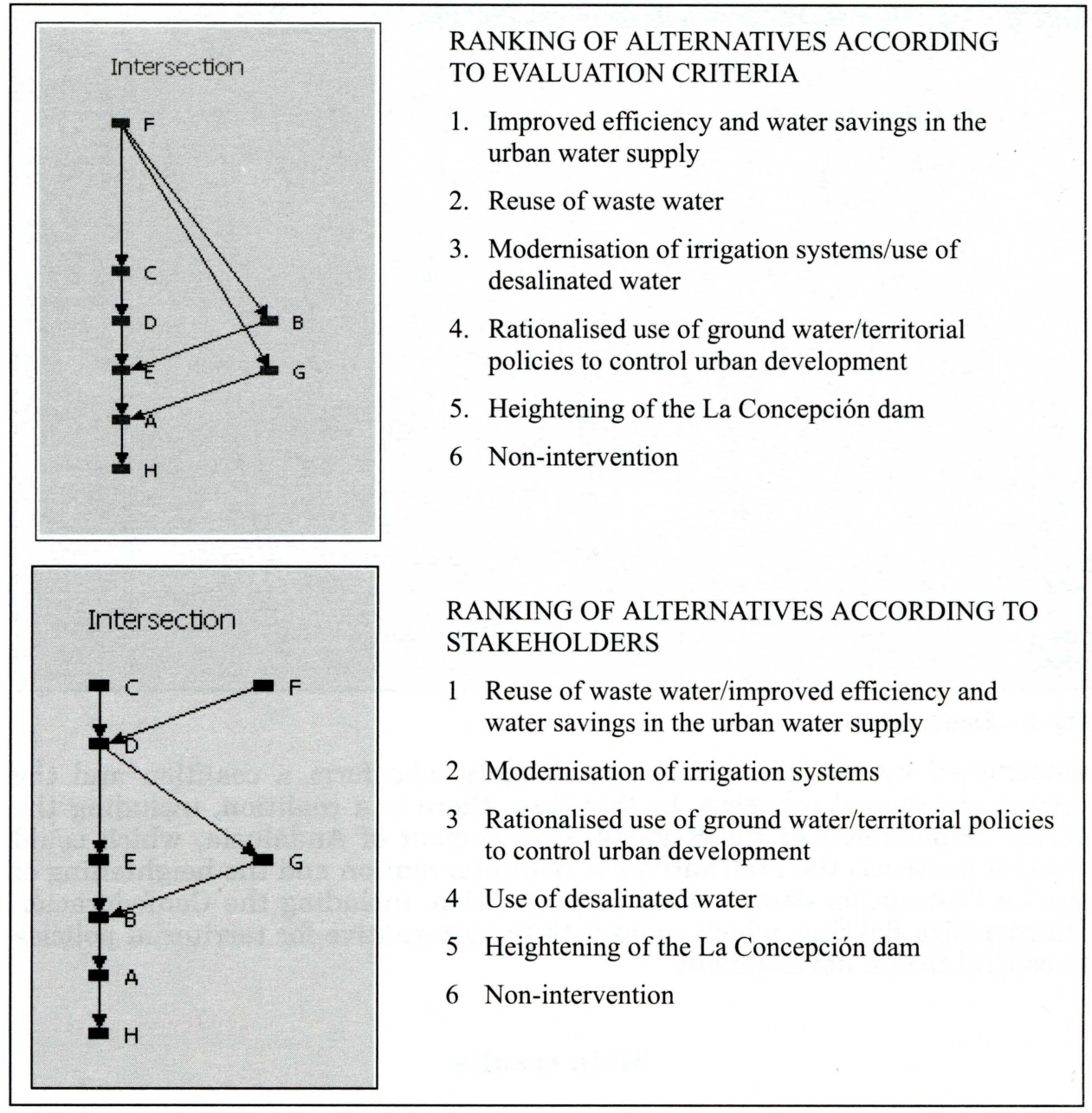

Fig. 5 - Ranking of alternatives according to evaluation criteria and stakeholders

determine the feasibility of an alternative it is necessary to consider the real power of each stakeholder or coalition of stakeholders. ${ }^{4}$ Based on these positions, a dendrogram of coalitions is produced. This is a graphic representation of the formation of possible "alliances" among stakeholders in the form of a tree diagram, which provides an insight into the degree of divergence.

Figure 6 shows the distances separating the stakeholders, which determines a greater or lesser degree of support for the alternatives evaluated. These coalitions will have what NAIADE terms power of veto, that is, the power to obstruct the implementation of any of the alternatives,

4 It is important to note that in multi-criteria evaluation using NAIADE, it is assumed that all the stakeholders are equally powerful and they are not weighted according to their real decision-making capacity. This may be a limiting factor in finding the best solution, but not in producing a ranking of alternatives according to their acceptability to stakeholders. 


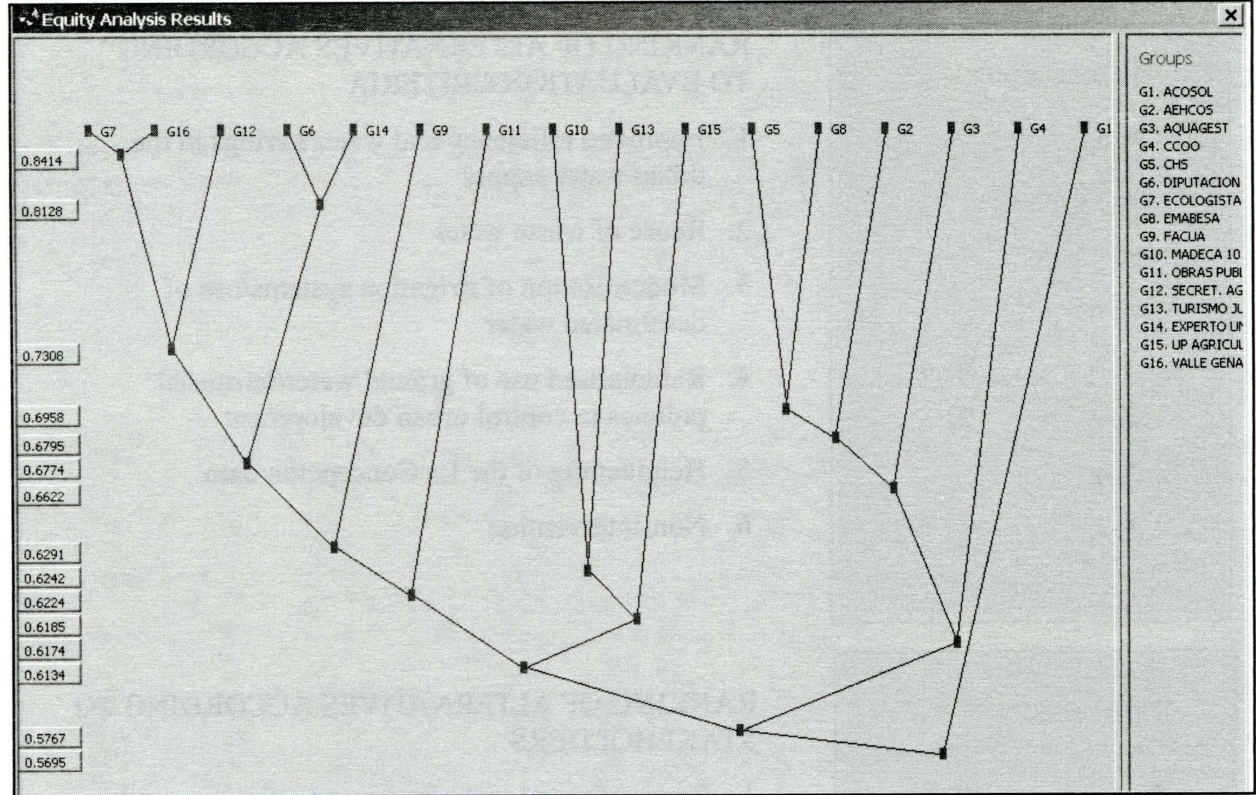

Fig. 6 - Dendrogram of coalitions

determined by the number of stakeholders who form a coalition and the degree of internal cohesion. In this case, there is a coalition, including the Water Department of the Regional Government of Andalusia, which could veto (or obstruct) the alternatives of non-intervention and the heightening of the La Concepción dam, and another coalition, including the Confederación Hidrográfica del Sur, which could veto the alternative for territorial policies to control urban development.

\section{Main results}

The evaluation process carried out with the aid of NAIADE revealed that in an open discussion framework social actors in the Costa del Sol area consider that the main issue is poor water resource management rather than a shortage of water. This demonstrates that in an open participatory discussion process, unconventional judgements of the situation may come to light, changing the identification of solutions and prioritisation of a given alternative by the stakeholders. In this case study, the primary focus was on the reuse of waste water, the modernization of irrigation systems and improved efficiency and water-saving measures in the urban water supply system. Measures to generate new conventional resources were also considered important, although not a top priority.

In the analyses carried out, there was no change in the two bottom-ranking alternatives, namely non-intervention and the heightening of the La Concepción dam, the main elements of the policy to increase conventional resources in the area, in spite of significant support from what has been termed the institutional framework. This leads to the conclusion that the most plausible alternatives for solving the water supply problem in the Costa 
del Sol Occidental area, that is, alternatives backed by the water management authorities, are not the best-performing alternatives in terms of economic, environmental and institutional criteria on a ten-year timeline or in terms of acceptance by stakeholders with legitimate interests in decisionmaking. This explains the heated debate on water resource management in the area and the objections raised with regard to certain alternatives. The preference of the competent public authorities for the construction of new hydraulic infrastructures in the province of Malaga to increase water regulation in coming years and for putting the Marbella desalination plant in operation in emergency situations is the result of institutional framework pressures, dictated by short-term considerations, and the failure to provide hydrological planning formulated as part of territorial reference planning. This is a concrete expression of the gap between reflection and real-life dynamics, and the failure to bridge this gap affects territorial policies and constitutes a major obstacle in the transition towards sustainable social organisation models.

Furthermore, when the preliminary results were presented to the stakeholders simultaneously in a focus group meeting, two considerations key to the analysis of this evaluation exercise were detected. First, when the stakeholders were presented with the final list of alternatives that had been worked on, they suggested the inclusion of other alternatives initially proposed by a small number of stakeholders, but not included in the final evaluation exercise precisely because they did not enjoy extensive support. Following an open debate, some of these alternatives (reforestation of catchment basins) figured among those receiving most support from the participating stakeholders. This shows that the latter phase in which all the stakeholders meet is crucial, because it can significantly change the final result, as issues overlooked during individual contacts are raised and debated. Second, in this phase of the participatory process the absence of certain sectors and, indirectly, the conflicts existing among them were noted. These stakeholders, who were reticent to attend the initial meetings, were mainly from the tourist sector and, more significantly, the authority responsible for water management in the area, Confederación Hidrográfica del Sur de Espana.

In summary, in the case study analysed, the proposed methodological approach proved to be a useful tool in dealing with water management conflicts, as it improved the quality and effectiveness of the decision-making process and contributed to determining which policy decisions could be best defended before all the stakeholders, thus reducing the degree of discrepancy and achieving a certain degree of consensus. By opening the social debate on water resource allocation to map all the implications, issues and interests involved, it is possible to find solutions that overcome inertia and look beyond short-term considerations, while averting and rationalising social conflict and resistance. However, it also highlighted the barriers that prevent the effective implementation of this type of evaluations, including the stakeholder conflict factor, in other words, the diverse and sometimes opposing values and interests at stake in water management issues.

\section{References:}

CIS-WG 2.9 (2002) Guidance on Public Participation in Relation to the Water Framework Directive - Active involvement, consultation and public access to information, Common 
Implementation Strategy Working Group 2.9, Brussels.

CORRAL, S. (2000) Una metodología integrada de exploración y comprensión de los procesos de elaboración de políticas públicas (EUR 19724 ES, Italy).

DE MARCHI et al. (2000): Combining Participative and Institutional Approaches with Multicriteria Evaluation. An Empirical Study for Water Issues in Troina, Sicily. Ecological Economics, 34, pp. 267-282.

DÜRRENBERG, D. et al. (1997): Focus Groups in Integrated Assessment: A Manual for a Participatory Tool. Darmstadt University of Technology, Darmstadt.

GUIMARĂES PEREIRA, Â., RINAUDO, J.-D., JEFFREY, P., BLASQUES, J., CORRAL QUINTANA, S., COURTOIS, N., FUNTOWICZ, S., PETIT, V. (2003): GOUVERNe project: ICT Tools To Support Public Participation In Water Resources Governance \& Planning: Experiences From The Design and Testing of a Multi-Media Platform. Journal of Environmental Assessment Policy and Management, 5, No. 3, pp. 395-420.

KASEMIR, B. et al. (1997): Focus Groups in Integrated Assessment: The ULYSSES Pilot Experience. Darmstadt University of Technology, Darmstadt.

McLAUGHLIN, P. (1992): Intervistare o essere intervitstai - L'arte di porre le domande e di rispondere. Franco Angeli, Milano.

MORGAN, D. L. (1998): The Focus Group Guidebook. SAGE Publications, London.

MUNDA, G. (1994) Fuzzy Information in Multi-Criteria Evaluation Environmental Models, EC JRC: EUR 14087 EN, Ispra, Italy.

MUNDA, G. (2002) Social Multi-Criteria Evaluation (SMCE): Methodological Foundations and Operational Consequences. Proceedings of the "Climate Change, Vulnerability and Adaptation: AIACC Development Workshop", Third World Academy of Sciences, Trieste, Italy, 3-14 June, 2002.

PANEQUE, P. (2003): Evaluación integrada de la gestión del agua en territorios vulnerables a riesgos hídricos: aplicación a la Costa del Sol Occidental (Málaga). Doctoral thesis. Department of Humanities, University of Pablo de Olavide.

VERA JURADO, D. (2003): Informe sobre la participación social y gestión de cuencas en Andalucía. Especial referencia a la Cuenca Hidrográfica del Sur, in Cuenca Hidrográfica del Sur, Informe de situación, Málaga: Foro de Málaga, CENTA.

VIDEIRA, N., ANTUNES, P., KALLIS, G., SANTOS, R., LOBO, G. (2002): Integrated Evaluation for Sustainable River Basin Governance. III Congreso Ibérico sobre Planificación y Gestión de Aguas. Leandro del Moral Ituarte, (coord.). Seville, University of Seville, Fundación Nueva Cultura del Agua and University of Pablo de Olavide, pp. 161-166.

\section{Shrnutí}

\section{NOVÁ RÁMCOVÁ SMĚRNICE EU O VODNÍM HOSPODÁŘSTVÍ A ÚČASTI V HODNOTÍCÍCH PROCESECH: VYUŽITÍ MULTIKRITERIÁLNÍCH NÁSTROJŮ PRO HODNOCENÍ MOŽNOSTÍ RIIZENÍ VODNÍHO HOSPODÁŘSTVÍ V COSTA DEL SOL (JIŽNÍ ŠPANĚLSKO)}

Rámcová směrnice Evropské Unie o vodním hospodár̆ství se má stát nástrojem politiky hospodaření $\mathrm{s}$ vodou zejména pokud jde o priority $\mathrm{v}$ racionálním využití vody, obnovení správného ekologického charakteru vodních ekosystémů a veřejného zastoupení - rozmanitých perspektiv a hodnot - při rozhodování jako životně důležitého nástroje pro dosažení těchto cílù. Tento dokument uvádí výsledky realizace procesu hodnocení za veřejné účasti při stanovení alternativ ruízení vodního hospodářství pro zásobování vodou oblasti Costa del Sol Occidental v provincii Malaga. V procesu byly použity techniky multikriteriálního hodnocení a výzkumu se zapojením účastníků uvedených $\mathrm{v}$ analýzách jako ústřední princip.

Multikriteria sociálního vývoje byly aplikovány při použití modelu NAIADE (Nový přístup $\mathrm{k}$ účinnému hodnocení a rozhodování o životním prostředí) navrženém v práci Munda (1994) a rozpracovaném Společným výzkumným střediskem v Ispra (Itálie) v roce 1995.

Proces hodnocení uskutečněný $\mathrm{s}$ pomoci NAIADE $\mathrm{v}$ této př́padové studii ukázal, že účastníci $\mathrm{z}$ oblasti Costa del Sol v rámcové otevřené diskusi dospěli $\mathrm{k}$ závěru, že hlavním problémem je špatné řízení využití vodních zdrojů spíše než nedostatek vody podle oficiálních zpráv. Navíc se ukazuje, že otevřená diskuse účastníků a nekonvenční posouzení stavu může snadno vést ke změně identifikace řešení a preferenci alternativy doporučené účastníky. V této př́ípadové studii bylo základním středem pozornosti opětovné použití od- 
padní vody, modernizace zavlažovacích systémů a zlepšení účinnosti úsporných opatření v městském systému zásobování vodou. Opatření vedoucí $\mathrm{k}$ vytváření nových konvenčních zdrojů byla také považována za důležitou, nikoliv však za prvořadou.

Dále, když předběžné výsledky byly předloženy účastníkům současně na skupinovém zasedání, byly zjištěny dva klíčové názory. Za prvé, když byli účastníci seznámeni s konečným seznamem alternativ, které byly vypracovány, navrhli zahrnutí dalších alternativ, navržených původně malým počtem účastníků, ale nezahrnutých do konečného hodnocení vzhledem $\mathrm{k}$ tomu, že nezískaly širokou podporu. Po otevřené debatě, některé $\mathrm{z}$ těchto alternativ (nové zalesnění vodních sběrných oblastí) figurovaly mezi těmi, které získaly největší podporu účastníků. To ukazuje, že pozdější etapa, v níž se všichni účastníci setkali, byla rozhodující, protože mohla podstatně změnit konečný výsledek, protože problémy během osobních setkání byly důkladně projednány. Za druhé v této etapě účastnického procesu nebyly zastoupeny některé úseky a tím nepřímo i některé konflikty existující mezi nimi. Ti účastníci, kteří byli na předchozích zasedáních zdrženliví, pocházeli hlavně z odvětví turistického ruchu a ještě významněji z orgánů odpovědných za hospodaření vodou v této oblasti Confederación del Sur de España.

Metodický postup navržený ve shrnutí analyzované případové studie prokázal, že je užitečným nástrojem při řešení konfliktů vodního hospodářství, jako je zlepšení kvality a účinnosti rozhodovacího procesu a přispěl ke zjištění, že politická rozhodnutí by mohla nejlépe obstát před všemi účastníky, snížit stupeň rozporů a vést $\mathrm{k}$ určitému stupni shody.

Otevřením společné diskuse o umístění vodních zdrojů po zmapování všech aspektů, problémů a zájmů je možné nalézt řešení $\mathrm{k}$ překonání setrvačnosti v myšlení a krátkodobých úvah a tím odvrátit a předcházet sociálním konfliktům a odporu. Avšak lze také překonat překážky, které brání účinnému uskutečňování tohoto typu hodnocení, včetně konfliktních faktorů účastníků, jinými slovy, rozdílným a někdy protichůdným hodnotám a zájmům při řešení otázek vodního hospodářství.

Obr. 1 - Schéma hodnocení (tetrahedron). Pramen: Videira a kol. (2002, s. 163)

Obr. 2 - Lokalizace a hranice oblasti, která byla předmětem studie. Pramen: digitální mapa Andalusie v měřítku: 1:100 000. Vlastní zpracování.

Obr. 3 - Diagram metodiky hodnotícího procesu (určení účastníků, vymezení problému, stanovení alternativ řízení vodního hospodářství, určení kritérii hodnocení alternativ, vyhodnocení alternativ, předběžné shrnutí výsledků, skupina otázek ve středu pozornosti, konečné vyhodnocení výsledků).

Obr. 4 - Účastníci zapojení v oblasti Costa del Sol Occidental (rozhodovací orgány, obchodní organizace, občanské organizace, experti)

Obr. 5 - Klasifikace alternativ podle kritérií hodnocení a účastníků. Klasifikace alternativ podle kritérií hodnocení: 1 . zlepšení účinnosti a úspory vody v zásobování měst vodou, 2. opětovné použití odpadních vod, 3. modernizace zavlažovacích systémů/využití odsolené vody, 4. racionalizace využití podzemních vod/územní plánování kontroly rozvoje měst, 5 . posílení koncepce přehrady, 6 . nevměšování. Klasifikace alternativ podle účastníků: 1 . opětovné použití odpadních vod/zlepšení účinnosti a úspory vody v zásobování měst vodou, 2 . modernizace zavlažovacích systémů, 3 . racionalizace využití podzemních vod/územní plánování kontroly rozvoje měst, 4 . využití odsolené vody, 5 . posílení koncepce přehrady, 6 . nevměšování.

Obr. 6 - Dendrogram srážek

(P. Paneque is with University of Pablo de Olavide,Department of Humanities, Carretera de Utrera km 1, 41013 Seville. Fax: +34954349817 ; e-mail: . S. Corral is with University of La Laguna, Department of Institutional Economics, Economic Statistics and Econometrics, Campus de Guajara s/n, 38071 La Laguna, S/C de Tenerife. Â. Pereira is with Institute for the Protection and Security of the Citizen, Joint Research Centre, European Commission. Via E. Fermi, 1, 21020 (VA) Ispra, Italy. L. del Moral and B. Pedregal are with University of Seville,Department of Human Geography, C/ Maria de Padilla s/n, 41004 Seville.) 